\title{
A Strategy for Improving the Functional Health and Well-Being of Cambodian University Faculty and Staff
}

\author{
Lee Fergusson $^{1} \&$ Anna Bonshek ${ }^{2}$ \\ ${ }^{1}$ Yudhishthira Professor of Vedic Science, Education and the Environment, Maharishi Vedic Research Institute, \\ Gold Coast, Australia; and \\ ${ }^{2}$ Mahagauri Professor of Art and Vedic Science, Maharishi Vedic Research Institute, Gold Coast, Australia \\ Emaill:lee@maharishivedicresearch.org
}

\begin{abstract}
The range of outcomes and published record on the Transcendental Meditation technique across 50 years of research in education, business, and government makes its application unique. Its association with health and relation to an individual's quality-of-life have also made the technique useful in some developing countries.

Data related to application of the technique to higher education in Cambodia have been accruing since the early 1990s. The 26-year research program begun by these authors associated with Transcendental Meditation and non-verbal intelligence, post-traumatic stress disorder, anxiety, depression, learning, memory, and personality in university students, as well as its collective effects on economic and social indicators and reductions in socio-political violence and crime, makes for an uncommonly rich body of knowledge in a country where empirical research has been rare. Indeed, the early studies in this research program represented among the first published research on higher education since the 1960s, after which Cambodia was plunged into civil war, genocide, and ongoing social turmoil and political conflict until 1993.

The present study, which is a modified version of a study previously published in ASEAN Journal of Education, extends this research program to include a preliminary investigation of the practice of Transcendental Meditation by faculty and staff in three regional Cambodian universities and examines its impact on health and well-being. Findings generated by a concurrent, quasi-experimental mixed methods design suggest the practice may be of benefit to university personnel as measured by physical mental and social health, perceived health, self-esteem, anxiety, and depression, among other quality-of-life variables, thereby adding to previous results associated with higher education in this increasingly important south-east Asian nation.
\end{abstract}

Keywords: Cambodia, functional health, well-being, quality-of-life, Transcendental Meditation, university faculty.

\author{
Abstrak \\ [Strategi untuk Meningkatkan Kesehatan Fungsional dan Kesejahteraan Fakultas dan Staf \\ Universitas Kamboja ]
}

Rentang hasil dan catatan yang dipublikasikan tentang teknik meditasi transendental selama 50 tahun penelitian baik dalam bidang pendidikan, bisnis, dan pemerintah menjadikan aplikasi teknik meditasi ini menjadi unik. Keterkaitan meditasi transendental dengan kesehatan dan hubungannya dengan kualitas hidup seseorang juga menjadikan teknik ini berguna di beberapa negara berkembang.

Data terkait penerapan teknik meditasi transendental pada pendidikan tinggi di Kamboja telah diperoleh sejak awal 1990-an. Program penelitian 26 tahun dimulai oleh para penulis yang terkait dengan Meditasi Transendental dan kecerdasan non-verbal, gangguan stres pasca-trauma, kecemasan, depresi, pembelajaran, memori, dan kepribadian pada mahasiswa, serta efek kolektifnya pada ekonomi dan indikator sosial, pengurangan kekerasan dan kejahatan sosio-politik, membuat akumulasi pengetahuan yang luar biasa kaya di negara di mana penelitian empiris jarang terjadi. Studi awal dalam program penelitian ini mewakili di antara penelitian pertama yang diterbitkan tentang pendidikan tinggi sejak 1960-an, setelah itu Kamboja terjerumus ke dalam perang saudara, genosida, kekacauan sosial dan konflik politik yang berkelanjutan hingga tahun 1993. Penelitian ini, yang merupakan versi modifikasi dari penelitian yang sebelumnya diterbitkan di ASEAN Journal of Education, memperluas program penelitian ini untuk memasukkan investigasi awal dari praktik 
meditasi transendental oleh fakultas dan staf di tiga universitas regional Kamboja dan meneliti dampaknya terhadap kesehatan dan kesejahteraan. Temuan yang dihasilkan oleh desain metode campuran kuasieksperimental mengindikasikan praktik ini mungkin bermanfaat bagi personil universitas yang diukur dengan kesehatan fisik dan mental sosial, kesehatan yang dirasakan, harga diri, kecemasan, dan depresi, di antara kualitas kehidupan lainnya variabel, dengan demikian menambah hasil sebelumnya yang terkait dengan pendidikan tinggi di negara Asia Tenggara yang menjadi semakin penting ini.

Kata kunci: Kamboja, kesehatan fungsional, kesejahteraan, kualitas hidup, meditasi transendental, fakultas universitas.

\section{INTRODUCTION}

Practice of the Transcendental Meditation technique by students, faculty and staff of colleges and universities has been a feature of the global higher education landscape since the $1970 \mathrm{~s}$. ${ }^{123}$

The Transcendental Meditation technique is described as a mental procedure practiced for 15-20 minutes twice a day while sitting comfortably with eyes closed. The technique does not require changes to personal belief, lifestyle, or philosophy (an important feature in a Roman Catholic country like Perú). Moreover, no mental effort is required to intentionally alter physiological or psychological processes or states, making it fundamentally different to mindfulness and other mental techniques which advocate concentration or mind control. However, the ordinary thinking process does become quiet and a distinct state of psychophysiological restful alertness, a wakeful but deeply restful state, is naturally gained.

The practice was introduced to Cambodian higher education and society in the early 1990s. ${ }^{45}$ For example, in January 1993, 550+ undergraduate students learned Transcendental Meditation during their inaugural year at Maharishi Vedic University (MVU) in Prey Veng province, with several thousand more learning the practice in subsequent academic years along with hundreds more learning the advanced Transcendental Meditation-Sidhi program. ${ }^{56}$ As part of that initiative to help reinvigorate Cambodia's higher education and healthcare sectors, officials and ministers of the Cambodian People's Party of the State of Cambodia learned the practice along with 300,000 people over a six-month period benefiting from Ayurvedic medical consultations provided free-of-charge to
Phnom Penh residents during 1991-1992. ${ }^{7}$ In addition, personnel of all ranks in the United Nations Transitional Authority of Cambodia (UNTAC) during 1992 and 1993, and a number of foreign ambassadors to Cambodia, also learned the practice as an integral part of a larger-scale international peace and social renewal effort. Such effort had been previously documented as part of a global campaign to create "Heaven on Earth" and global green revolution, of which Cambodia, being the poorest country in the world in 1990, had been singled out for special attention. ${ }^{8}$ Prior research conducted since 1970 indicated that Transcendental Meditation has a salutary effect on the mental, physical, and behavioural health of practitioners, and this global research program has been well documented in the published literature over many years. ${ }^{91011} 12131415$ Indeed, more than 600 published findings suggest the practice contributes to the quality-of-life of individuals, families, schools, workplaces and society more generally, as conceptualised by the mechanisms proposed in Figure 1.

In Figure 1, which highlights examples of research conducted over a 50-year period, we show the relationship between practice of the Transcendental Meditation technique and improved 'quality-of-life' (a construct associated with general 'wellbeing, ${ }^{16}$ with the shaded boxes representing the key elements of the present study). The practice has previously been associated with quality-of-life indicators. For example, it has been identified with increased brainwave coherence, ${ }^{1718}$ which has been associated with reduced depression, anxiety, and neuroticism and increased selfesteem and self-actualisation, ${ }^{19} 202122 \quad 23$ which in turn have been causally linked to an overall improvement in mental (i.e., 
psychological) health.

Similarly, since the 1970s, research has shown the practice produces a profound state of physiological rest, ${ }^{242526}$ along with other biochemical and functional markers of restfulness, and these have been associated with reduced levels of stress and stress reactivity, sickness, and medical and hospital utilisation rates, ${ }^{27282930}$ decreased patho -genesis and progression of disease ${ }^{31}$ and increased cardiovascular disease prevention and health promotion, ${ }^{32}$ which together have resulted in improvements to overall physical health and well-being. ${ }^{33}$

As a consequence of these impacts on mental and physical health, practice of Transcendental Meditation has also been associated with improved attitudes and behaviour, such as an increased capacity for warm relations with others and acceptance of aggression and improved moral reasoning ${ }^{34}$ including in the behaviour of society's most damaged individuals in maximum security prisons $^{35}$ and those addicted to non- prescription drugs. $^{36}$

Research has thereby found that interpersonal relations at work and in the home $^{37}$ and an individual's social health improve as a result of the practice. ${ }^{38} 3940$ More recent research has found that practice of Transcendental Meditation is more effective in treating post-traumatic stress disorder (PTSD) than traditional methods of exposure therapy and health education. ${ }^{41}$ Nidich, et al. showed that $61 \%$ of a sample of U.S. war veterans diagnosed with symptoms of clinical PTSD experienced improvements in severity of symptoms as a result of 12-week's practice of Transcendental Meditation, compared to $42 \%$ of veterans who received prolonged exposure therapy and $32 \%$ who received health education alone. ${ }^{41}$ A similar trend in symptoms of clinical depression was also observed in that study. Together, the above studies indicate that Transcendental Meditation improves a person's quality-of-life. ${ }^{42} 43$

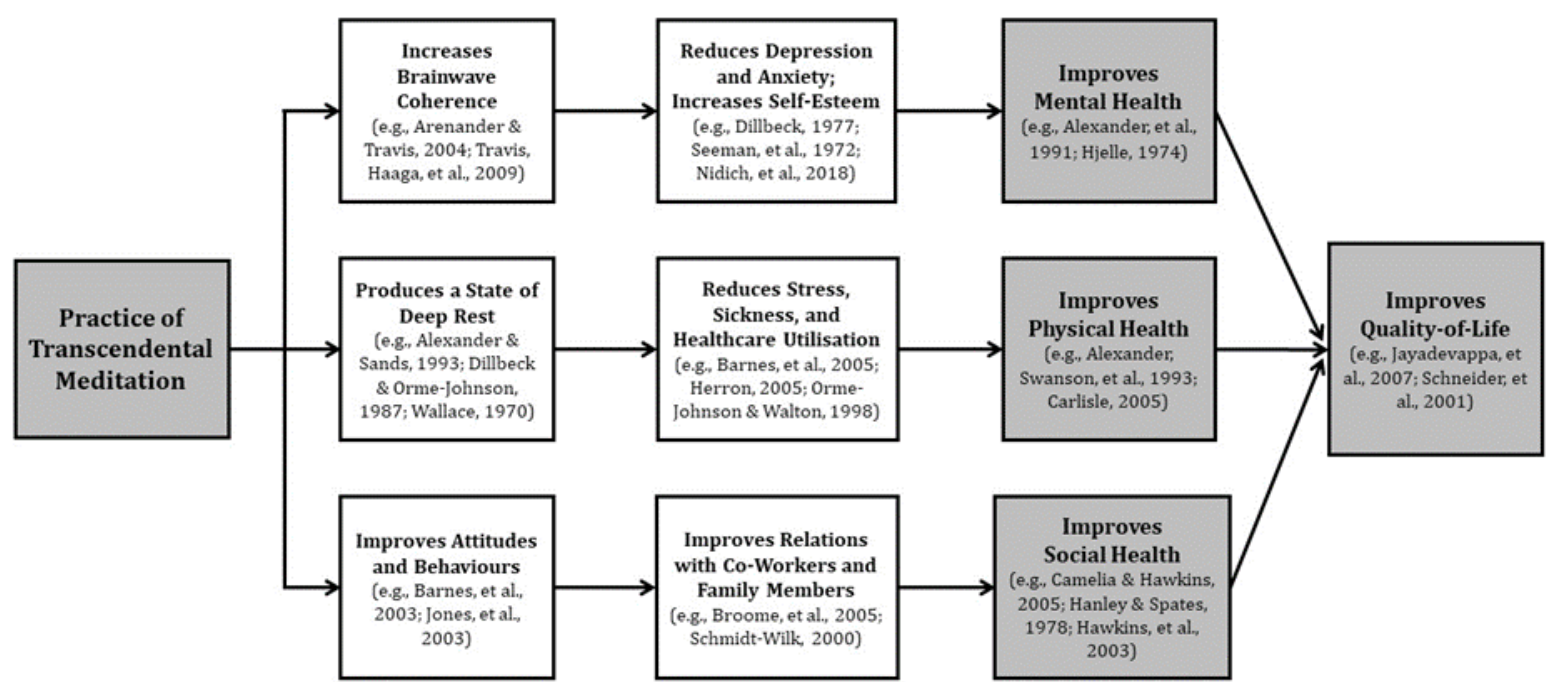

Figure 1 Conceptual model of Transcendental Meditation and its relationship to mental, physical and social health and to quality-of-life.

Figure 1 proposes certain links between elements, for example between Transcendental Meditation > brainwave coherence $>$ reduction in depression $>$ improved mental health $>$ improved quality of life. However, it is not within the scope of this paper to explain the theoretical framework for this model nor the casual and/or correlational links it posits, but such theory and supporting research have been presented in more detail elsewhere. ${ }^{44} 45$

Of relevance to this study is the research program conducted by these authors, beginning in 1993 with the advent of MVU where the practice of Transcendental Meditation was incorporated into the curriculum, which investigated a range of outcomes, including those associated with increased 
non-verbal intelligence, ${ }^{46}$ decreased PSTD symptoms and improved health characteristics of Cambodian undergraduates, ${ }^{47}$ factors of relevance to higher education in Cambodia during the early $1990 \mathrm{~s},{ }^{48}$ and social, socio-political, and economic impacts. ${ }^{649} 50$ This research program has even been extended to analyses of Cambodia's history of higher education and teacher education and to the role MVU played in revitalising them. ${ }^{45152}$ However, application of Transcendental Meditation to promote the health of Cambodian university faculty and staff has not been explored.

The primary purpose of this study is therefore to examine this topic using ten indicators (i.e., the dependent variables for this study), which have been referred to as measures of 'health-related quality-oflife' (HRQoL). As will be discussed below, six of these indicators are synonymous with 'functional health' and four are synonymous with 'dysfunctional health' according to Parkerson and others associated with Duke University who developed the instrument we used. 55545556

We ask the following research question (RQ): Did practice of the Transcendental Meditation technique have a salutary effect on the HRQoL of Cambodian university faculty and staff as measured by physical health, mental health, social health, general health, perceived health, self-esteem, anxiety, depression, pain and disability?

\section{METHOD}

Research Design. This study used a concurrent, quasi-experimental mixed methods research design with a major quantitative (QUAN) strand and minor qualitative (qual) strand applied across a four-month, longitudinal control-treatment period. The pre- and post-test QUAN measure was applied to both the Control Group and Treatment Group, while the minor preand post-test qual measure was applied only to a sub-set of the Treatment Group, with a view to converging the Treatment Group QUAN and qual strands, as shown by the double-arrowed dotted line in Figure 2.

Participants. Three regional Cam-bodian universities were selected as investigation sites for this research. In co-operation with the management of 1) Cambodian University of Specialties (CUS) in Kampong Cham city, Kampong Cham, 2) Chea Sim University at Kamcheymear (CSUK) in Kamcheymear, Prey Veng, and 3) University of Management and Economics (UME) in Kampong Cham city, Kampong Cham, 39 faculty and staff members were selected for participation in this study. All participants in the study were native Khmers, and no demand characteristics (e.g., incentives to preform or other expectations) were utilised in the research. Twelve volunteer participants from CUS (Group One: female = 8 ; male $=4$; age $M=23.5 ; S D=5.0$ ) and 11 volunteer participants from CSUK (Group Two: female $=4$; male $=7$; age $M$ $=26.0 ; S D=7.2$ ) based on convenience, availability and scheduling. Fourteen participants in the UME group (Group Three: female $=7$; male $=7$; age $M=29.8 ; S D=$ 11.3) represented the faculty cohort who volunteered to learn the Transcendental Meditation technique as part of their employment benefits package. At pre-test, all groups were similar for gender and educational level, and a one-way analysis of variance (ANOVA) for the three groups yielded no significant difference in age $(F=2.05, p$ $=.14)$.

For this reason, Groups One and Two were statistically amalgamated to form the Control Group and Group Three became the Treatment Group. Both the Control and Treatment Groups were pretested in March and post-tested in July 2018. All participants were administered the Duke Health Profile (DUKE) in single sessions at each university. Five volunteers from the Treatment Group (female $=2$; male $=3$; age $M=26.0$ ) were interviewed at the end of each pre- and post-test session to provide qual data on HRQoL. Independent translators were in attendance to provide clarification on the meaning of any terms or phrases used in the DUKE and interviews, but faculty and staff participants, school and research administrators, and translators were blind to the purpose of the study. Attrition was a problem in this study, with approximately $20 \%$ of partici- 
pants unavailable for post-QUAN testing due to scheduling; casewise completion analysis was used to minimise the effect of attrition.

Quantitative Instrument. To measure the HRQoL construct, the DUKE was chosen for the QUAN strand of the study. The DUKE is a 17-item generic self-report, paper-and-pencil instrument containing ten measures of health function. These include six functional health measures of physical health (five items), mental health (five items), social health (five items), general health (15 items), perceived health (one item), and self-esteem (five items) (note, some of the 17 items in the DUKE are used in more than one measure of HRQoL). The score range for measures of health function are $0-100$, with a higher score representing a higher level of health, self-esteem and perceived health. The DUKE also includes four dysfunctional health measures of anxiety ( $\mathrm{six}$ items), depression (five items), pain (one item), and disability (one item) ${ }^{53}$ 55565758 The score range for measures of health dysfunction are $0-100$, with a higher score representing a lower level of anxiety, depression, pain or disability. This study used a Khmer cross-translated version of the DUKE, which was developed and tested with permission, ${ }^{47}$ although the translation has not been validated (for example, by backward translation ${ }^{59}$ ) beyond a committee of experts.

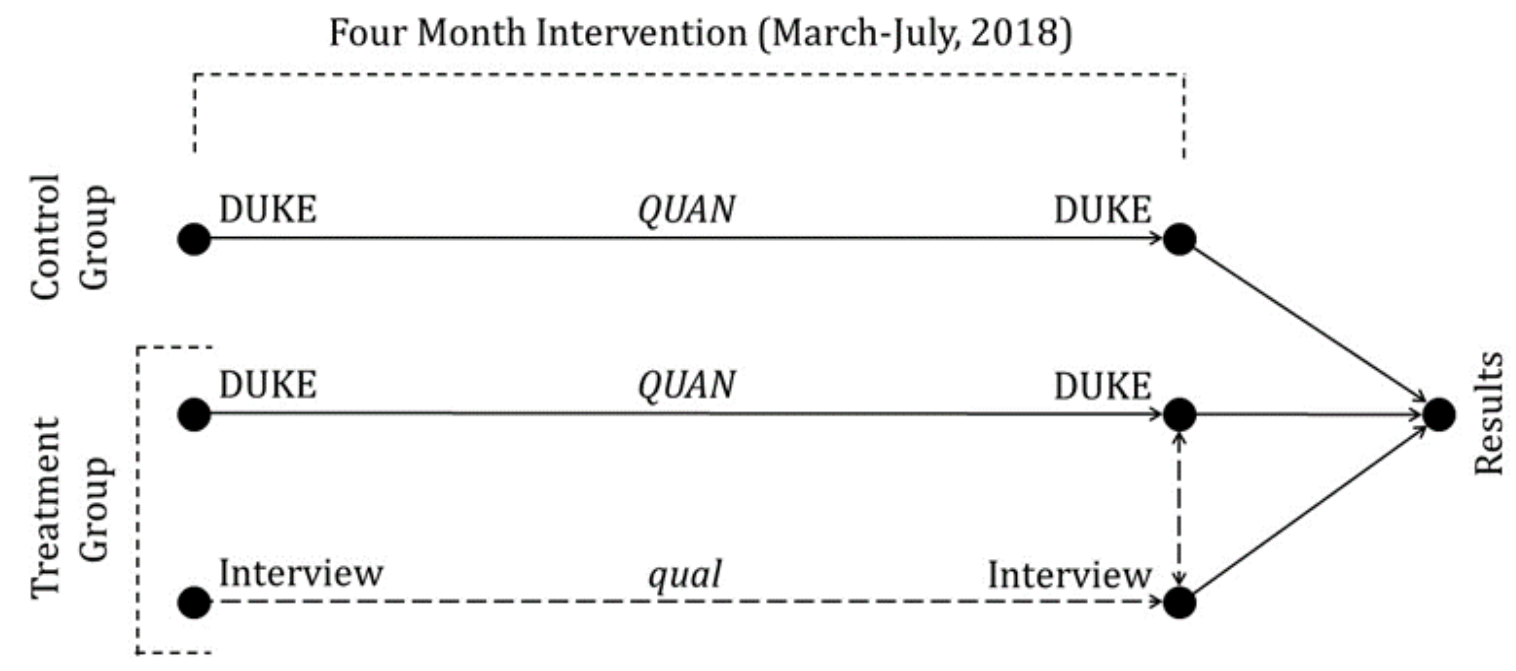

Figure 2 Concurrent, quasi-experimental mixed methods research design showing the relationship of QUAN and qual measures for Control and Treatment Groups.

The DUKE's authors state the instrument is designed "to measure patientreported health-related quality-of-life (HRQoL), i.e., functional health status, during a one-week time period"53 and provide the following definitions for the ten variables. According to Parkerson, the physical health scale measures physical capacity for ambulation (i.e., walking and running) and physical symptoms (i.e., sleeping, fatigue, and pain). The mental health scale measures psychological symptoms (i.e., depressed feelings and nervousness), cognition (i.e., concentrating), and personal selfesteem (i.e., like who I am, and give up too easily). ${ }^{53}$ The social health scale measures participation in social activities (i.e., socialise with friends or relatives, and participate in group activities), and social self-esteem (i.e., not easy to get along with, comfortable around people, and happy with family relationships). The general health scale represents combined physical, mental, and social health by averaging the scores for those three scales. The perceived health scale scores the patient's self-assessment of overall health by a response to what extent $\mathrm{s} / \mathrm{he}$ is "basically a healthy person".53

The self-esteem scale measures personal self-esteem (i.e., like who I am, and give up too easily) and social self-esteem (i.e., not easy to get along with, comforta- 
ble around people, and happy with family relationships). The anxiety scale measures anxiety with social self-esteem items (i.e., not easy to get along with, comfortable around people, and happy with family relationships), psychological symptoms (i.e., nervousness), and somatic symptoms (i.e., sleeping and fatigue). The depression scale measures depression with personal selfesteem items (i.e., like who I am, and give up too easily) and the psychological symptoms (i.e., depressed feelings) and somatic symptoms (i.e., sleeping and fatigue) that are used on the anxiety scale. The pain scale measures pain for "hurting or aching in any part of your body".53 The disability scale measures confinement to "home, nursing home, or hospital because of sickness, injury, or other health problem" during the preceding week.53

Items used in the DUKE were derived from the 63-item Duke-UNC Health Profile (DUHP) based upon face validity and item-remainder correlations. ${ }^{60}$ Reliability of the DUKE has been confirmed by Cronbach alphas ( $\alpha=0.55$ to 0.78$)$ and test -retest correlation coefficients $(r=0.30$ 0.78 ), and convergent and discriminant validity has been supported by score correlations between the DUKE and three other standardised instruments: 1) Sickness Impact Profile; 2) Tennessee Self-Concept Scale; and 3) Zung Self-Rating Depression Scale. ${ }^{535456}$

Moreover, clinical validity has been supported by differences between the health scores of patients with clinically different health problems. ${ }^{53}$ For example, U.S. patients with painful physical problems have a DUKE physical health mean score of $M=$ 58 , while patients with only health maintenance problems have a mean score of $M=$ 84 (scale: $0=$ poorest health and $100=$ best health). Patients with mental health problems have a DUKE mental health mean score of $M=49$, in contrast to $M=76$ for patients with painful physical problems and $M=79$ for those with only health maintenance problems. A more detailed analysis of the DUKE's psychometric quality is provided by Parkerson. ${ }^{53}$ The DUKE's authors have also adapted two of the DUKE's 17 items for use in the Adolescent Duke Health Profile (ADHP) and applied it for reliability and validity testing in $1,816 \mathrm{Vi}$ etnamese youths. ${ }^{59}$

The ADHP indicated satisfactory internal consistency, construct validity and test-retest reliability. ANOVAs, when tested at the $p \leq .05$ two-tailed level on each of the ten HRQoL measures of the DUKE in this study, showed that excepting mental health and self-esteem (which were borderline significant), there was no significant difference between Control Group and Treatment Group scores at pre-test on these measures: physical health: $F=0.96, p$ $=.39$; mental health: $F=3.20, p=.05$; social health: $F=1.27, p=.29$; general health: $F=2.73, p=.07$; perceived health: $F=0.71, p=.49$; self-esteem: $F=3.89, p$ $=.03$; anxiety: $F=1.20, p=.31$; depression: $F=2.05, p=.14$; pain: $F=2.25, p$ $=.12$; and disability: $F=0.18, p=.82$. Pearson product-moment correlation coefficient analyses at the $p \leq .05$ level were conducted on the ten pre-test HRQoL variables (e.g., between mental health and anxiety) as an informal check of the DUKE's construct validity.

Qualitative Interviews. Interviews consisting of a series of nine demographic questions (asked at pre-test) and 12 semistructured questions related to $\mathrm{HRQoL}$ (asked at pre- and post-test) were conducted for the Treatment Group qual strand. The demographic questions asked about place of birth, place of residence, educational background, current level of qualification, hobbies and interests, and current position and responsibilities in the university. The 12 semi-structured questions included: how would you describe your present state of physical health, any specific health problems, how would you describe your present state of mind, any specific mental health problems, are you generally nervous or anxious about life or work, do you participate in social activities outside of work, how frequently do you participate in social activities, are you happy in your home life, do you feel happy going to work each day, and are you happy with your present work circumstances? The following 
demographic data about the de-identified Treatment Group interviewees were obtained at pre-test:

Participant \#1: OP is a 32-year old female born in Koak Kang commune in Kampong Cham province who currently resides in Sanghat Sambour Meas, Kampong Cham city. She has a Masters' degree in management but wishes to gain a Ph.D. and "start my own business". SS is chief quality assurance officer, responsible for registering and archiving student grades, and enjoys singing, sightseeing, and gardening.

Participant \#2: BT is a 26-year old female born in Prasat commune in Prey Veng province who currently resides in Sanghat Sambour Meas, Kampong Cham city. She has a Masters' degree in accounting and finance and wishes to learn more about research in accounting and finance as a way of "strengthening my teaching quality". BT is chief financial officer, responsible for managing university cash flow. Participant \#3: TA is a 21-year old male born in Prasat commune in Prey Veng province who currently resides Sanghat Sambour Meas, Kampong Cham city. He has an undergraduate degree in management and currently serves as an administrative assistant responsible for managing students and attendant lists. TA listed "internet searching" as his main hobby but would also like to pursue a Masters' and Ph.D. degree in the future.

Participant \#4: RM is a 29-year old male born in Koyme commune in Bantaey Mean Chey province who currently resides in Snay Sambou Meas commune, Kampong Cham province. RM holds a Masters' degree in law and is the university's administrative deputy director responsible for managing staff, reporting student progress, planning managing the school property and physical plant. He enjoys playing football and sightseeing while not at work; RM stated that he is not "seeking to expand my qualifications".

Participant \#5: LN is a 22-year old male born in Prasat commune in Prey Veng province who currently resides in Sanghat Sambour Meas, Kampong Cham city. He is a student and part-time staff member who is working toward a degree in management and economics. LN is the university's cashier and helps with "cash management" at the university; he plays volleyball and enjoys "searching the internet", particularly YouTube, in his spare time.

Data Analysis. Different analytical and explanatory processes were used in this study. In addition to the aforementioned ANOVAs, tests of difference (paired ttests) and MANOVAs tested at the $p \leq .05$ two-tailed level between pre- and post-test Control Group and Treatment Group on casewise completion scores on the ten HRQL dependent variables were conducted. ${ }^{60}$ Although the integer responses of the self-reported ratings are not normally distributed, simulation studies have offered strong support for the appropriateness of parametric analyses such as $t$-tests and ANOVA, even with as few as two or three ordered categories for each response item. ${ }^{61}$ 62

Effect size is a useful representation of an intervention's effect and is generally accepted among social scientists and by the American Psychological Association. Effect size can be defined as the degree to which the phenomenon is present in the population or the magnitude of the impact of the intervention on the outcome. Thus, an effect size is an index for describing the magnitude of an intervention's effect. Hedges' effect sizes were calculated to measure the standardised difference between treatment and comparison. ${ }^{63}$ Computing $g$ for each variable under investigation can determine the effect size and we note that Hedges' method is more suitable than Cohen's when group sample sizes are $<20$. Using Cohen's method of reporting effect sizes as a guide, ${ }^{64}$ we have applied the following criteria: small to medium $g=0.2$ 0.5 (estimated bias never exceeds 0.4 , according to Hedges et al. ${ }^{65}$ medium to large $g=0.5-0.8$; large to extremely large $g>$ 0.8 , however we also recognise Hedges' caution about reporting effect sizes. ${ }^{63}$

Given that the five pre- and posttest interview transcripts, which were translated from the original Khmer into English 
by co-authors four and five, did not consist of extensive (or rich) qual data but shorter descriptive statements, basic content analysis was used to describe so-called 'manifest' or literal communications content. ${ }^{66}$ Coding of responses was carried out by two independent raters from the University of Southern Queensland (who were unaffiliated with this study and blind to its RQ and purpose).

Unlike interpretive content analysis, which requires interpretive judgement, basic content analysis relies mainly on frequency counts of low-inference events that are manifest or literal.

In this case, instances of reported changes on combined physical health, mental health and social health were rated between 0-3 at pre-test and again at post-test, with ' 0 ' representing manifestly no or limited physical, mental and social health and ' 3 ' representing manifestly high physical, mental and social health. On this scale, a change in either direction of one point on the scale represents a $33 \%$ change in HRQoL.

Ethics and Consent. This research was approved by the Maharishi Vedic Research Institute (MVRI) research ethics approval committee and by the Chairpersons of each university, and was conducted under the terms of the MVRI Code of Research Practice and Procedure, which conforms to the Australian Code for the Responsible Conduct of Research, approval number MVRI-2019-17.

\section{RESULTS}

Quantitative Results. The difference between changes on the ten HRQoL variables in Control Group and Treatment Group pre-test and post-test means $(M s), S D$ s, tests of difference, and probability values are presented in Table 1.

From this data, the following may be observed. When tested at the $p \leq .05$ two -tailed level, there was no statistically significant difference between the pre-test scores and the post-test scores of any of the ten HRQoL variables for the Control Group $(d f=24)$. However, there was a difference between the pre-test score and the post-test scores on every HRQoL variable, except disability, for the Treatment Group $(d f=$ 13). Multiple analyses of variance (MANOVAs) on changed scores between the Control and Treatment groups yielded results for treatment effects shown in Table 2.

From these data, the following effects can be observed: when tested at the $p$ $\leq .05$ two-tailed level, significant and marginally significant statistical variations between the changed scores of the control and treatment groups were observed for mental health, social health, general health, perceived health, self-esteem and anxiety, while variations for physical health, depression, pain and disability were not significant. MANCOVAs using pre-test score as the co-variate yielded similar results.

The standardised mean difference in effect sizes is shown in Table 3. Medium effect sizes were observed for physical health, perceived health, depression and pain, large effect sizes were observed for social health, self-esteem, and anxiety, and extremely large effect sizes were observed for mental health and general health. A non-existent effect size occurred for disability.

These findings are largely consistent in direction with those reported by MANOVAs in Table 2, but case effect sizes for physical health, social health, perceived health, self-esteem anxiety, depression and pain more closely resemble the data in Table 1.

Pearson product-moment correlation coefficients indicated the functional and dysfunctional scores of the DUKE for all participants were correlated for the following variables: self-esteem and anxiety were negatively correlated, $r=-.66, p$ $=.00001$; anxiety and depression were positively correlated, $r=.78, p=.00001$; selfesteem and depression were negatively correlated, $r=-.52, p=.0007$; mental health and depression were negatively correlated, $r=-.79 ; p=.00001$, mental health and anxiety were negatively correlated, $r=-.69$, $p=.00001$; and mental health and perceived health were positively correlated, $r$ $=.29, p=.01$.

Qualitative Results. Content analy- 


\section{WMJ (Warmadewa Medical Journal), Vol. 5 No. 1, Mei 2020, Hal. 38}

sis of the five pre-test and post-test interviews yielded the following HRQoL ratings, as shown in Table 4: OP increased $\mathrm{HRQoL}=33 \%$; $\mathrm{BT}$ increased $\mathrm{HRQoL}=$
$66 \%$; TA increased HRQoL = 33\%; RM increased $\mathrm{HRQoL}=33 \%$; and $\mathrm{LN}$ increased HRQoL $=33 \%$.

Table 1 Pre- and Post-Test Means and SDs and Tests of Difference and Probability of HRQoL Variables for Control and Treatment Groups.

\begin{tabular}{|c|c|c|c|c|c|c|}
\hline Variable & $\begin{array}{c}\text { Pre-test } \\
\text { Mean }\end{array}$ & Pre-test $S D$ & $\begin{array}{c}\text { Post-test } \\
\text { Mean }\end{array}$ & Post-test $S D$ & $t$ & $p$ \\
\hline \multicolumn{7}{|l|}{ Control Group } \\
\hline Physical Health & 55.6 & 13.6 & 56.9 & 14.4 & 0.45 & .32 \\
\hline Mental Health & 61.2 & 13.6 & 62.3 & 17.4 & 0.31 & .37 \\
\hline Social Health & 72.4 & 13.9 & 68.5 & 9.9 & -1.97 & .96 \\
\hline General Health & 63.1 & 10.0 & 62.5 & 10.5 & -0.23 & .59 \\
\hline Perceived Health & 66.0 & 27.8 & 61.5 & 21.9 & -1.03 & .84 \\
\hline Self-Esteem & 80.8 & 16.1 & 76.9 & 13.2 & -1.47 & .92 \\
\hline Anxiety & 59.9 & 15.1 & 54.4 & 14.1 & -0.02 & .96 \\
\hline Depression & 55.2 & 16.1 & 55.4 & 18.1 & 0.05 & .48 \\
\hline Pain & 60.0 & 25.0 & 65.4 & 20.0 & 0.12 & .54 \\
\hline Disability & 76.0 & 29.3 & 80.8 & 25.3 & 0.94 & .17 \\
\hline \multicolumn{7}{|l|}{ Treatment Group } \\
\hline Physical Health & 55.0 & 17.9 & 66.4 & 16.3 & 2.61 & .01 \\
\hline Mental Health & 49.3 & 19.0 & 70.9 & 16.4 & 4.98 & .0001 \\
\hline Social Health & 66.4 & 15.5 & 78.2 & 14.0 & 3.15 & .007 \\
\hline General Health & 56.9 & 13.1 & 71.8 & 12.7 & 4.39 & .0003 \\
\hline Perceived Health & 60.7 & 28.9 & 72.7 & 26.1 & 1.72 & .05 \\
\hline Self-Esteem & 68.6 & 15.6 & 80.0 & 10.0 & 4.36 & .001 \\
\hline Anxiety & 52.4 & 17.4 & 66.5 & 16.8 & 3.14 & .003 \\
\hline Depression & 50.7 & 13.8 & 67.3 & 11.9 & 5.21 & .00008 \\
\hline Pain & 39.3 & 35.0 & 59.1 & 30.2 & 2.50 & .01 \\
\hline Disability & 82.1 & 31.7 & 81.8 & 33.7 & -0.03 & .51 \\
\hline
\end{tabular}

Table 2 Multiple Analyses of Variance on Changed Scores for Control Group and Treatment Group HRQoL Variables.

\begin{tabular}{|l|c|c|c|c|}
\hline \multicolumn{1}{|c|}{ Variable } & $\begin{array}{c}\text { Control Group } \\
\text { Changed Scores }\end{array}$ & $\begin{array}{c}\text { Treatment Group } \\
\text { Changed Score }\end{array}$ & $\boldsymbol{F}$ & $\boldsymbol{p}$ \\
\hline Physical Health & 2.3 & 7.3 & 1.03 & 0.3 \\
\hline Mental Health & 3.1 & 21.8 & 7.62 & .01 \\
\hline Social Health & -2.3 & 10.9 & 2.89 & .09 \\
\hline General Health & 1.0 & 13.3 & 7.54 & .01 \\
\hline Perceived Health & -7.7 & 18.2 & 3.42 & .08 \\
\hline Self-Esteem & -2.3 & 10.9 & 3.86 & .07 \\
\hline Anxiety & -2.2 & 12.8 & 4.16 & .06 \\
\hline Depression & 3.8 & 14.5 & 1.92 & .17 \\
\hline Pain & -3.8 & 13.6 & 1.44 & .14 \\
\hline Disability & 3.8 & 0 & 0.03 & .84 \\
\hline
\end{tabular}


Table 3 Effect Sizes for Control Group and Treatment Group HRQoL Variables.

\begin{tabular}{|l|c|c|}
\hline \multicolumn{1}{|c|}{ Variable } & Hedges $g$ & Effect Size \\
& & Medium \\
\hline Physical Health & 0.42 & Extremely Large \\
\hline Mental Health & 1.42 & Large \\
\hline Social Health & 0.72 & Extremely Large \\
\hline General Health & 1.25 & Medium \\
\hline Perceived Health & 0.65 & Large \\
\hline Self-Esteem & 0.78 & Large \\
\hline Anxiety & 0.84 & Medium \\
\hline Depression & 0.48 & Medium \\
\hline Pain & 0.55 & Non-existent \\
\hline Disability & 0.09 & Pan \\
\hline
\end{tabular}

Table 4 Pre- and Post-Test HRQoL Ratings for Treatment Group Interview Participants

\begin{tabular}{|l|c|c|c|c|}
\hline \multirow{2}{*}{ Participant } & \multicolumn{4}{|c|}{ Pre-Test Rating to Post-Test Rating } \\
\hline & 0 & 1 & 2 & 3 \\
\hline $1: O P$ & & Pre-test & Post-test & \\
\hline $2: B T$ & & Pre-test & & Post-test \\
\hline $3: T A$ & & & Pre-test & Post-test \\
\hline $4: R M$ & & Pre-test & Post-test & \\
\hline $5: L N$ & & & Pre-test & Post-test \\
\hline
\end{tabular}

These ratings were derived from transcribed interview data, which are summarised below for each of the five participants:

Participant \#1: At pre-test, OP stated that her present state of physical health was "average"; sometimes "I am feeling well and sometimes not", with a breathing problem (i.e., an allergic cough) recurring since childhood. OP reported that her present state of mind could be described as "tired", and although recently "feeling happy" was generally nervous and anxious about life and work.

She did present as someone who was socially outgoing, and attended "many weddings", but as with her physical health OP indicated not always feeling happy going to work with worries about "how to achieve the tasks and quality with less time available". OP stated that her home life with four relatives was stable.
At post-test, OP reported her physical health was "in good condition" with no specific health problem. Similarly, she reported that her present state of mind was "normal with no specific mental health problem although she was still anxious about work because "it is complicated". Asked about her social activities outside of work, OP indicated that she was not engaged, but did feel positive about work and "was happy upon waking and having breakfast, and then "start working and organising things"; she is happy with her present work situation but would like to further her education in law. From this data, a general improvement in OP's quality-oflife from pre-test Rating 1 to post-test Rating 2 was observed.

Participant \#2: BT described her pre -test physical health as "normal, but sometimes with a little bit of a headache", and as having an "eye problem when looking at 
the computer screen for too long". She also described her mental health as "stress at work [having "big responsibilities", with the "more work to do, the more stress" she is having]. BT also reported that she was also "anxious at home when having too much work, and she "gets no help from her husband". Sometimes she feels happy but other times not, and she "wants [her] husband to share some of the housework" which he does not; such a home situation makes her anxious. Asked about her social activities outside work, BT responded that she "rarely" gets involved in activities outside of work, but when she does, such as participating in charitable acts, she feels "happy". BT similarly reported that her home life is not going so well due to the aforementioned issues with her husband's home contribution, but that overall work is satisfying, despite being of a routine nature, especially when there is an increase in the number of students.

At post-test, BT reported her physical health was again "normal, but [I] have been affected by the colds of others", however she reported no specific physical health problems. BT described her present state "normal, and [I] want to learn a foreign language so that I can travel abroad". BT stated: "I was nervous and anxious before learning Transcendental Meditation but now I am not; I have been able to release stress more quickly than before". BT also reported that she had visited Bangkok in the previous week, and "unlike before, I can deal with my family issues; there seems to be more mutual understanding between myself and my husband"; "we are getting on well together, better now compared to before".

BT stated that she is happy going to work and think about finances and ensuring there is enough money "to proceed the work"; "I can now delegate some work to subordinates, which makes me feel release and fresher than before". From this data, a general improvement in BT's quality-of-life from pre-test Rating 1 to post-test Rating 3 was observed.

Participant \#3: At pre-test, TA stated that his physical health was normal, but that he "looks thin"; he reported that he sometimes "catches a cold kind of disease". TA presented as mentally balanced with "no [general or specific] problem; I think of myself as creative, for example I updated a work form given by the director, making it more useful by adding my ideas on it" and with no nervousness or anxiety. He also said he was socially outgoing and enjoyed "doing charity work, such as participating in the university charity event distributing books to poor children in remote school areas". TA stated that he got on well with his four brothers and eight sisters, all of whom live at home, and is happy with work: "the first thing I think of when starting the day at work is to clean the room before doing any tasks".

At post-test, TA stated his physical and mental health was normal with no specific problem or anxiety, with a happy home life and well-integrated sociability. From this data, a general improvement in TA's quality-of-life from pre-test Rating 2 to post-test Rating 3 was observed.

Participant \#4: RM reported at pretest that his physical health was not good, with "something growing inside his nose" causing difficulty with breathing. He also reported that sometimes he slept late and would wake-up late, with feelings of pain in his legs and arms and being unable to site comfortably cross-legged. RM also reported feelings of anxiousness, and not thinking clearly, especially when there was a lot of work to do; RM stated that he "was not thinking broadly enough". Mentally, he stated that his memory was impaired and that he was "forgetting things a lot", and that he felt his thinking was "slow". RM did, however, report that he often played football and "even led a football competition", and that he participated in charitable works, such as "giving books to poor children, and educating them about health, but only did this twice a year. He stated that he was happy at home and that he feels happy at work, starting first by "checking the overall physical environment of the school and then governing students' overall interaction in the school".

At post-test, RM reported signifi- 
cant changes. He still had the pain in his leg but that it was getting better, but his breathing was still difficult. However, his mental state had improved significantly, and he felt "normal and fresh", with no anxiety but still with minor memory loss. RM stated that he had been to Thailand in the preceding month to participate in a conference associated with Transcendental Meditation. Asked whether he was "generally happy with his home life" he stated "Yes!" and that his home life was good with everyone "getting on well together". RM also said he was happy with his present work circumstances and felt happy to go to work and supervise staff. From this data, a general improvement in RM's quality-of-life from pre-test Rating 1 to post-test Rating 2 was observed.

Participant \#5: LN at pre-test described his physical health as normal with no specific health issues, and his mental state as "tough" but also "thinking a lot and forgetting things sometimes, especially when there is a lot of work to do". He also stated that he sometimes "felt stressful, particularly in relation to a lot of work". LN stated that he can be nervous and anxious but only "once-in-a-while" participates in social activities, such as involvement in Environment Day once a year. He described his home life as generally happy, but that his five siblings living at home did not always get along with their father, who also live in the house.

However, generally LN said that he was happy going to work each day "because I can use my own capacity to support my family by just completing my duties". LN did report that he felt stress at work and would like to finish work earlier, and while generally happy at work, was not happy with his present work situation, particularly when "my superior does not use good words, I feel upset".

At post-test, LN stated that his health was normal, and he did not get sick "even under circumstances of changing environment and atmosphere", although he did get "a little headache". His experience of stress related to "increased work" remained the same, but he did not present with any specific mental health problem. $\mathrm{LN}$ also reported his participation in extracurricula events, such as workshops, seminars, and World Environment Day as a highlight of his life. While not obvious why, LN reported there were now 12 people living in his house, including his parents, and that all of them got on well; and he felt happy at work, first "thinking about organising the workplace, then finishing off work from the previous day, before starting on tasks associated with the new work day". From this data, a general improvement in LN's quality-of-life from pre-test Rating 2 to post-test Rating 3 was observed.

\section{DISCUSSION}

The difference in changed QUAN scores on HRQoL variables of the Control Group and Treatment Group is unequivocal. While no significant difference was observed between the pre-test scores and the post-test scores of any HRQoL variable for the Control Group, there was a statistically significant difference observed between the pre-test score and the post-test scores on every HRQoL variable, except disability, for the Treatment Group. [Unlike the HRQoL scores of patients in a clinic or hospital, it can reasonably be argued that in a sample of $20+$ year-old faculty and staff a change in 'disability' would be unlikely, which was the case for both Control and Treatment Groups.

Similarly, effect sizes comparing the Control Group and Treatment Group ranged between medium and extremely large, except as noted above for disability, but only changed scores on two of the ten variables, mental health and general health, were significantly different, and thus further research is required to examine and explain observed changes, especially longer term changes, among the other eight variables associated with HRQoL in Cambodian faculty.

In this study, as in the earlier study in Cambodia using the DUKE, ${ }^{47}$ average pre- and post-test mean scores for the earlier two Control Groups who did not practice the Transcendental Meditation technique 
did not change significantly: general health pre- $M=58.9(S D=15.85)$ and post $-M=$ $62.7(S D=15.4)$; self-esteem pre- $M=69.0$ $(S D=18.1)$ and post $-M=73.0(S D=$ 14.6); and depression pre- $M=58.5(S D=$ $15.8)$ and post $-M=58.1(S D=15.4)$.

The pre- and post-test scores for the Treatment Group in that earlier study, who practiced the Transcendental Meditation technique, however, changed significantly: general health pre- $M=66.3(S D=12.4)$, post$M=75.4(S D=10.7), F=4.76, p=.001$; self-esteem pre- $M=75.0(S D=17.5)$ and post- $M=82.4(S D=11.0), F=2.98, p$ $=.05$; and depression pre- $M=63.6(S D=$ $14.7)$ and post- $M=72.7(S D=16.1), F=$ 5.31, $p=.01$.

Control Group and Treatment Group scores and trends for general health, self-esteem and depression in both the earlier and present studies are largely consistent. For example, in both studies general health was approximately $M=60.0$ at pretest and post-test (average 3.5\% change, $p$ $=$ not significant) in the Control Groups, but general health was pre- $M=66.3$ in the Treatment Group increasing to post- $M=$ 75.4 (a 14\% increase, $p=.001$ ) in the earlier study, and was pre- $M=56.9$ in the Treatment Group increasing to a significant post- $M=71.8$ (a 25\% increase, $p=.0003$ ) in the present study.

These findings can be compared to normative ADHP data from Vietnam (Hanh, et al., 2005), although the age ranges in that study were younger than the present study (i.e., 12-19 year olds). In the Hahn et al. study, physical health $M=83.0$, mental health $M=73.0$, social health $M=$ 57.5, general health $M=71.5$, perceived health $M=60.0$, self-esteem $M=67.0$, anxiety $M=74.0$, depression $M=76.5$, pain $M=81.0$, disability $M=96.5$ (all with comparable $S D$ s). These data indicate that except for perceived health and self-esteem, all HRQoL indicators were considerably lower in Cambodia than in Vietnam.

These findings in Cambodia can also be compared to normative DUKE data of 17,733 people between the ages of 12-75 in France, ${ }^{67}$ which yielded DUKE scores for physical health $M=72.0$, mental health
$M=77.0$, social health $M=67.0$, general health $M=71.0$, perceived health $M=$ 71.0 , and self-esteem $=77.0$, respectively. Dysfunction scores were anxiety $M=69.0$, depression $M=72.0$, pain $M=66.0$, and disability $M=97.0$, respectively. From these data it can be shown that on almost every HRQoL indicator, at pre-test participants of the present study rated their current physical health, mental health, general health, perceived health, self-esteem anxiety, depression and pain well below these normative French averages, but on each variable were at, or close to, normative means at post-test (e.g., French norm for general health $M=71$; pre-test $M=56.9$ and post-test $M=71.8$ in this study).

Of distinction is social health, with the French norm $M=67.0$; pre-test $M=$ 66.4 and post-test $M=78.2$ in this study, although disability scores for both pre- and post-test in the present study were lower than the French norm. Across all HRQoL measures, both French normative data and the findings of this and the earlier study of practitioners of Transcendental Meditation in Cambodia are generally (and predictably) higher than patients in Macedonia with signs and symptoms indicative of needing coronary angiography but who had no other previously diagnosed serious health issues, mental disorder, or any form of disability when tested on the DUKE. ${ }^{68}$

Given the potentially large score range for each variable (i.e., 0-100), outlier impact on the changed scores was calculated to determine if any of the data were skewed, ${ }^{69}$ however only one borderline outlier for a physical health changed-score of one participant in the Treatment Group was observed, and therefore we conclude the present data were not skewed and outliers did not impact the observed results.

The secondary qual data also suggest a general improvement of physical health, mental health, and social health in the sub-set Treatment Group. Four interviewees were rated as experiencing an overall improvement in HRQoL of 33\%, with BT reporting an improvement of $66 \%$. Of interest is the finding that BT identified the practice of Transcendental Meditation 
as being the cause of her improved qualityof-life with the words: "I was nervous and anxious before learning Transcendental Meditation but now I am not; I have been able to release stress more quickly than before".

Of note also is the observation that her association between Transcendental Meditation $>$ improved mental health, which we have associated with improved quality-of-life in this study, is largely consistent with the conceptual model presented in Figure 1. Nevertheless, the present study does not provide insight into causal relations between the mechanistic processes and theoretical elements posited by Figure 1 , and further factor analysis and other analytical techniques would be required to establish the nature of these relations in Cambodia.

A placebo effect cannot be entirely ruled out in this study. However, previous research on the application of Transcendental Meditation to measures of health, stress, and quality of life, including measures of trait anxiety, ${ }^{70} 71$ self-actualisation, ${ }^{20}$ alcohol and drug abuse, ${ }^{72}$ and blood pressure ${ }^{73}$

74 suggest practice of the Transcendental Meditation technique and not a placebo effect is the likely cause of HRQoL changes observed in Cambodia.

Limitations associated with nonrandom selection and assignment to groups in the current research design should also be noted, however again several of the above meta-analyses controlled for nonrandom assignment to treatment, and the findings reported herein are consistent with those earlier studies which showed Transcendental Meditation was the likely causal factor in improved health and observed effects were not the result of expectation, demand characteristics, special treatment, attention, or selection bias. But this conclusion nevertheless has not been established by this design.

\section{CONCLUSION}

The evidence derived from the QUAN strand for both the Control Group and Treatment Group and from the convergence of data in both the QUAN and qual strands of this mixed methods design for the Treatment Group suggest that the Transcendental Meditation technique has a salutary effect on the physical health, mental health and social health of university faculty and staff participants in Cambodia, and this finding is consistent with those derived from the earlier study with Cambodian undergraduates and from other higher education settings.

As a result of these preliminary findings, the research question associated with improved quality-of-life in Cambodia can tentatively be answered in the affirmative.

We therefore propose that application of the Transcendental Meditation technique by Cambodian university faculty and staff may result in more widespread quality -of-life benefits and thus a general improvement in well-being and health, and that further mixed methods research with a larger faculty and staff cohort in Cambodia would add confirmatory evidence for this conclusion.

\section{REFERENCES}

1. Beaufort M, Bonshek A, Fergusson L. The Holistic Education of Artists through Maharishi Vedic Science: Unfolding the Infinite Reservoir of Creativity in Individual Awareness. Modern Science and Vedic Science 1997; 7(1): 269-95.

2. Dillbeck MC, Aron AP, Dillbeck SL. The Transcendental Meditation Program as an Educational Technology: Research and Applications. Educational Technology 1979; 19: 7-13.

3. Jones C, Akura G. Addressing the 'Wicked Problems' of Sustainability through Consciousness-based Education. Journal of Maharishi Vedic Research Institute 2017; 4: 75-124.

4. Fergusson L, Bonshek A (editors). Maharishi Vedic University in Cambodia: Educational reconstruction and social renewal. Gold Coast, Australia: Prana World Publishing, 2013.

5. Fergusson L, Bonshek A (editors). Maharishi Vedic University in Cambodia: Educational reconstruction and 
social renewal $2^{\text {nd }}$ edition. Gold Coast, Australia: Prana World Publishing, 2017.

6. Fergusson LC, Cavanaugh KL. Socio -political Violence in Cambodia between 1990 and 2008: An Explanatory Mixed Methods Study of Social Coherence. Studies in Asian Social Science 2019; 6(2): 1-45.

7. Australian Aid for Cambodia Fund. Cambodia Report: Newsletter for the Australian Aid for Cambodia Fund, 2, Melbourne, Australia, November 1993.

8. Maharishi Vedic University. Maharishi's master plan to create heaven on earth: Reconstruction of the whole world. Vlodrop, The Netherlands: Maharishi Vedic University Press, 1991.

9. Chalmers R, Clements G, Schenkluhn $H$, Weinless $M$ (editors). Scientific research on Maharishi's Transcendental Meditation and TM-Sidhi programme: Collected papers, volume 2 . The Netherlands: Maharishi Vedic University Press, 1989a.

10. Chalmers R, Clements G, Schenkluhn $\mathrm{H}$, Weinless $\mathrm{M}$ (editors). Scientific research on Maharishi's Transcendental Meditation and TM-Sidhi programme: Collected papers, volume 3. The Netherlands: Maharishi Vedic University Press, 1989b.

11. Chalmers R, Clements G, Schenkluhn $\mathrm{H}$, Weinless $\mathrm{M}$ (editors). Scientific research on Maharishi's Transcendental Meditation and TM-Sidhi programme: Collected papers, volume 4. The Netherlands: Maharishi Vedic University Press, 1989c.

12. Dillbeck MC (editor) Scientific research on Maharishi's Transcendental Meditation and TM-Sidhi program: Collected papers, volume 6. Fairfield, Iowa: Maharishi University of Management Press, 2011.

13. Dillbeck MC (editor). Scientific research on Maharishi's Transcendental Meditation and TM-Sidhi Program: Collected papers, volume 7. The Netherlands: Maharishi Vedic Uni- versity Press, 2013.

14. Orme-Johnson DW, Farrow JT (editors). Introductions reprinted from scientific research on the Transcendental Meditation program: Collected papers, volume 1. Rheinweiler, West Germany: Maharishi European Research University Press, 1976.

15. Wallace RK, Orme-Johnson DW, Dillbeck MC (editors). Scientific research on Maharishi's Transcendental Meditation and TM-Sidhi program: Collected papers, volume 5. Fairfield, Iowa: Maharishi International University Press, 1990.

16. Robinson M. Encyclopedia of Quality of Life and Well-being Research. Reference Reviews 2015; 29(7): 222.

17. Arenander A, Travis FT. Brain Patterns of Self-awareness. In Beitman B, Nair J, editors. Self-awareness deficits. New York, NY: WW Norton; 2004. p. 112-26.

18. Travis F, Haaga DA, Hagelin JS, Tanner M, Nidich S, Gaylord-King C. Effects of Transcendental Meditation Practice on Brain Functioning and Stress Reactivity in College Students. International Journal of Psychophysiology 2009; 71(2): 170-76.

19. Dillbeck MC. The Effect of the Transcendental Meditation Technique on Anxiety Level. Journal of Clinical Psychology 1977; 33(4): 1076-78.

20. Alexander CN, Rainforth MV, Gelderloos P. Transcendental Meditation, Self-actualization, and Psychological Health: A Conceptual Overview and Statistical Meta-analysis. Journal of Social Behavior and Personality 1991; 6(5): 189-247.

21. Hjelle JA. Transcendental Meditation and Psychological Health. Perceptual and Motor Skills 1974; 39(5): 623-28.

22. Sakairi, Y. Effects of Transcendental Meditation for reducing anxiety in Japanese businessmen. In: Blows M, Srinivasan S (editors), Perspectives on relaxation and meditation, Melbourne: Spectrum Publications, 1992. p. 163-75. 
23. Seeman W, Nidich S, Banta T. Influence of Transcendental Meditation on a Measure of Self-actualization. Journal of Counseling Psychology 1972; 19(3): 184-87.

24. Alexander CN, Sands D (1993). Meditation and relaxation. In: McGill, FN, editor, McGill's guide of the social sciences: Psychology. Pasadena, California: Salem Press; 1993, p. 1499-1505.

25. Dillbeck MC, Orme-Johnson DW. Physiological Differences Between Transcendental Meditation and Rest. American Psychologist 1987; 42(9): 879-81.

26. Wallace RK. Physiological Effects of Transcendental Meditation. Science 1970; 167: 1751-54.

27. Barnes VA, Schneider RH, Alexander CN, Rainforth M, Staggers F, Salerno J. Impact of Transcendental Meditation on Mortality in Older African Americans with Hypertension-Eight -year Follow-up. Journal of Social Behavior and Personality 2005; 17 (1): 201-216.

28. Gaylord C, Orme-Johnson D, Travis F. The Effects of the Transcendental Meditation Technique and Progressive Muscular Relaxation on EEG Coherence, Stress Reactivity, and Mental Health in Black Adults. International Journal of Neuroscience 1989; 46(1/2): 77-86.

29. Herron RE. Can the Transcendental Meditation Program Reduce Medical Expenditures of Older People? A Longitudinal Medical Cost Minimization Study in Canada. Journal of Social Behavior and Personality 2005; 17(1): 415-42.

30. Orme-Johnson DW, Walton KG. All Approaches to Preventing and Reversing the Effects of Stress are Not the Same. American Journal of Health Promotion 1998; 12(5): 29799.

31. Chhatre S, Metzger DS, Frank I, Boyer J, Thompson E, Nidich S, Montaner LJ, Jayadevappa R. Effects of Behavioral Stress Reduction Tran- scendental Meditation Intervention in Persons with HIV. AIDS Care 2013; 25(10): 1291-97.

32. Schneider RH, Walton KG, Salerno JW, Nidich SI. Cardiovascular Disease Prevention and Health Promotion with the Transcendental Meditation Program and Maharishi Consciousness-Based Health Care. Ethnicity \& Disease 2006; 16(3): Supplement 4, 15-26.

33. Alexander CN, Swanson GC, Rainforth MV, Carlisle TW, Todd CC, Oates RM. Effects of the Transcendental Meditation Program on Stress Reduction, Health, and Employee Development: A Prospective Study in Two Occupational Settings. Anxiety, Stress and Coping 1993; 6: 245-62.

34. Barnes VA, Bauza LB, Treiber FA. Impact of Stress Reduction on Negative School Behavior in Adolescents. Health and Quality of Life Outcomes 2003; 1(1): 10.

35. Abrams AI, Siegel LM. The Transcendental Meditation Program and Rehabilitation at Folsom State Prison: A Cross-Validation Study. Criminal Justice and Behavior 1978; 5(1): 3-20.

36. Aron A, Aron EN. The Pattern of Reduction of Drug and Alcohol Use Among Transcendental Meditation Participants. Bulletin of the Society of Psychologists in Addictive Behaviors 1983; 2(1); 28-33.

37. Broome JR, Orme-Johnson D, Schmidt-Wilk J. Worksite Stress Reduction through the Transcendental Meditation Program. Journal of Social Behavior and Personality 2005; 17(1): 235-76.

38. Camelia CR, Hawkins MA (2005). The Use of Meditation with At-risk Youth in the Netherlands Antilles. Caribbean Journal of Criminology and Social Psychology 2005; 10(1/2): 102-140.

39. Hanley CP, Spates JL. Transcendental Meditation and Social-psychological Attitudes. Journal of Psychology 1978; 99: 121-27. 
40. Hawkins MA, Alexander CN, Travis FT, Camelia CR, Walton KG, Durchholz CF. Consciousness-based Approach to Rehabilitation of Inmates in the Netherlands Antilles: Psychosocial and Cognitive Changes. Journal of Offender Rehabilitation 2003; 36(1 -4): 205-228.

41. Nidich S, Mills PJ, Rainforth M, Heppner P, Schneider R, Rosenthal NE. Non-trauma-focused Meditation Versus Exposure Therapy in Veterans with Post-traumatic Stress Disorder: A Randomized Controlled Trial. The Lancet Psychiatry 2018; 5(12): 97586.

42. Jayadevappa R, Johnson JC, Bloom BS, Nidich S, Desai S, Chhatre S. Effectiveness of Transcendental Meditation on Functional Capacity and Quality of Life of African Americans with Congestive Heart Failure: A Randomized Control Study. Ethnicity and Disease 2007; 17: 72-7.

43. Schneider RH, Nidich SI, Salerno JW. The Transcendental Meditation Program: Reducing the Risk of Heart Disease and Mortality and Improving Quality of Life in African Americans. Ethnicity \& Disease 2001; 11: 15960.

44. Alexander $\mathrm{CN}$, Boyer R, Alexander $\mathrm{V}$. Higher States of Consciousness in the Vedic Psychology of Maharishi Mahesh Yogi: A Theoretical Introduction and Research Review. Modern Science and Vedic Science 1987; 1 (1): 89-126.

45. Schmidt-Wilk J, Orme-Johnson DW, Alexander VK, Schneider RH. Applications of Maharishi Vedic Science: Honoring the Lifework of Charles N. Alexander, PhD. A Special Issue of the Journal of Social Behavior and Personality 2005; 17(1).

46. Fergusson L, Bonshek A, Le Masson G. Vedic Science-based Education and Nonverbal Intelligence: A Preliminary Longitudinal Study in Cambodia. Higher Education Research and Development 1996; 14(1): 73-82.

47. Fergusson L, Bonshek A, Boudigues
J-M. Personality and Health Characteristics of Cambodian Undergraduates: A Case for Student Development. Journal of Instructional Psychology 1995; 22(4): 308-19.

48. Fergusson L, Bonshek A, Boudigues M. Transcendental Meditation and Five Factors Relevant to Higher Education in Cambodia. College Student Journal 1994; 28(1): 103-7.

49. Fergusson L. Vedic Science-based Education, Poverty Removal and Social Well-being: A Case History of Cambodia from 1980 to 2015. Journal of Indian Education (Journal of the National Council of Educational Research and Training) 2016a; 41(4): 16-45.

50. Fergusson L. The Impact of Maharishi Vedic University on Cambodian Economic and Social Indicators from 1980 to 2015. Journal of Maharishi Vedic Research Institute 2016b; 2: 77 -135 .

51. Fergusson L, Le Masson G. A Culture Under Siege: Post-colonial Higher Education and Teacher Education in Cambodia from 1953 to 1979 . History of Education 1997; 26(1): 91112.

52. Fergusson L, Le Masson G, Bonshek A. A Descriptive Analysis of Cambodian Higher Education and Teacher Education from 1979 to the Present. Education Research and Perspectives 1996; 22(2): 132-48.

53. Parkerson GR. User's guide for the DUKE health measures. Durham, NC: Department of Community and Family Medicine, Duke University, 2002.

54. Parkerson GR. The Duke Health Profile (DUKE). In: Michalos AC (editor), Encyclopedia of quality of life and well-being research. Dordrecht: Springer, 2014.

55. Parkerson GR, Broadhead WE, Tse C -K. The Duke Health Profile: A 17item Measure of Health and Dysfunction. Medical Care 1990; 28(11): 1056-72.

56. Parkerson GR, Broadhead WE, Tse C 
-KJ. Development of the 17-item Duke Health Profile. Family Practice 1991; 8: 396-401.

57. Parkerson GR, Broadhead WE, Tse C-KJ. Quality of Life and Functional Health of Primary Care Patients. Journal of Clinical Epidemiology 1992; 45(11): 1303-13.

58. Parkerson GR, Broadhead WE, Tse C-KJ. Anxiety and Depressive Symptom Identification Using the Duke Health Profile. Journal of Clinical Epidemiology 1996; 49(1): 85-93.

59. Hanh VTX, Guillemin F, Cong DD, Parkerson GR, Thu PB, Quynh PT, Briançon S. Health Related Quality of Life of Adolescents in Vietnam: Cross-cultural Adaptation and Validation of the Adolescent Duke Health Profile. Journal of Adolescence 2005; 28: 127-46.

60. Parkerson GR, Gehlbach SH, Wagner EH, James SA, Clapp NE, Muhlbaier LH. The Duke-UNC Health Profile: An Adult Health Status Instrument for Primary Care. Medical Care 1981; 19: 806-28.

61. Carifio J, Perla R. Ten Common Misunderstandings, Misconceptions, Persistent Myths and Urban Legends about Likert Scales and Likert Response Formats and Their Antidotes. Journal of Social Sciences 2007; 3: 106-16.

62. Harpe SE. How to Analyze Likert and Other Rating Scale Data. Currents in Pharmacy Teaching and Learning 2015; 7: 836-50.

63. Hedges LV. What are Effect Sizes and Why Do We Need Them? Child Development Perspectives 2008; 2(3): 167-71.

64. Orwin RG. A Fail-safe N for Effect Size in Meta-analysis. Journal of Educational Statistics 1983; 8(2): 15759.

65. Hedges LV, Pustejovskya JE, Shadish WR. A Standardized Mean Difference Effect Size for Single Case Designs. Research Synthesis Methods 2012; 3: 224-39.
66. Drisko JW, Maschi T. Content analysis. Oxford, UK: Oxford University Press, 2016.

67. Baumann C, Erpelding M-L, PerretGuillaume C, Gautier A, Régat S, Collin J-F, Guillemin F, Briançon S. Health-related Quality of Life in French Adolescents and Adults: Norms for the DUKE Health Profile. BMC Public Health 2011; 11: 401.

68. Dojcinovski I, Naumoska L, Ristovska F, Mitrev Z. Body Mass Index and Quality of Life in Patients Waiting for Coronary Angiography: A Pilot Study. Psychology, Community \& Health 2014; 3(1): 11-22.

69. Liao H, Li Y, Brooks GP. Outlier Impact and Accommodation on Power. Journal of Modern Applied Statistical Methods 2017; 16: 261-78.

70. Eppley K, Abrams A, Shear J. Differential Effects of Relaxation Techniques on Trait Anxiety: A Metaanalysis. Journal of Clinical Psychology 1989; 45(6): 957-974.

71. Orme-Johnson DW, Barnes VA. Effects of the Transcendental Meditation Technique on Trait Anxiety: A Meta-analysis of Randomized Controlled Trials. Journal of Alternative and Complementary Medicine 2013; 19: 1-12,

72. Alexander CN, Robinson P, Rainforth MV. (1994). Treating and Preventing Alcohol, Nicotine, and Drug Abuse through Transcendental Meditation: A Review and Statistical Metaanalysis. Alcoholism Treatment Quarterly 1994; 11(1/2): 13-87.

73. Anderson JW, Liu C, Kryscio RJ. Blood Pressure Response to Transcendental Meditation: A Metaanalysis. American Journal of Hypertension 2008; 21(3); 310-316.

74. Bai Z, Chang J, Chen C, Li P, Yang $\mathrm{K}$, Chi I. Investigating the Effect of Transcendental Meditation on Blood Pressure: A Systematic Review and Meta-analysis. Journal of Human Hypertension 2015; 29(11): 653-62. 